\title{
Production Budget for Bell Peppers in Southwest Florida1
}

John VanSickle, Scott Smith, and Eugene McAvoy ${ }^{2}$

\section{Overview}

Bell peppers are an important crop to the state of Florida, with southwest Florida being the second largest production area. Statewide, Florida harvested 17,500 acres of bell peppers during the 2006-07 growing season, valued at $\$ 183$ million dollars (Table 1). In 2007, acreage planted to bell pepper in Florida decreased 10 percent while acreage harvested increased by 6.7 percent. Yield per acre (28-pound bushels) peaked in the 2003-04 season at a state average of 1,107 bushels, and has averaged in the range of 861 to 886 bushels over the last three seasons. Production in Florida increased 7 percent in 2007 while value per bushel (dollars) decreased 8.2 percent. Overall, the total value of Florida's bell pepper crop has decreased 16 percent since the 2003 season.

\section{Production Practices}

Bell pepper production practices vary considerably across the major Florida production areas. Most of the state's bell pepper crop is transplanted in double rows on polyethylene-mulched raised beds using either drip or seep irrigation technology. Methyl bromide in combination with chloropicrin is applied prior to planting transplants on more than 70 percent of Florida's bell pepper acreage for the management of soil insects, pathogens, nematodes, and weeds (especially nutsedge), all of which are major pests in bell pepper production. Approximately 33 percent of the Florida growers use stakes and twine around the bed perimeter to construct "corrals" to contain the plants. Standard spacing is six feet between bed centers, with plants typically planted ten inches apart. Bell peppers are usually hand harvested at least twice during the growing season. South Florida pepper growers may harvest up to five times in profitable market conditions.

\section{Production Budgets}

Table 2 is a per-acre composite budget breaking down specific cost components used to estimate the budget expense categories and total estimated production cost per acre. The budget is intended to reflect the cost of production using representative production practices that are considered typical for bell peppers grown in southwest Florida. What

1. This is EDIS document FE810, a publication of the Food and Resource Economics Department, Florida Cooperative Extension Service, Institute of Food and Agricultural Sciences, University of Florida, Gainesville, FL. Published December 2009. Please visit the EDIS website at http://edis.ifas.ufl.edu.

2. John VanSickle, professor, Food and Resource Economics Department, University of Florida, Gainesville, FL; Scott Smith, economic analyst, Food and Resource Economics Department, University of Florida, Gainesville, FL; and Eugene McAvoy, county extension director, Hardee County Extension, LaBelle, FL, Florida Cooperative Extension Service, Institute of Food and Agricultural Sciences, University of Florida, Gainesville, FL. 
constitutes a representative production practice is defined by a consensus of opinion of UF/IFAS field experts, industry experts, and various producers in the production area. Cost estimates resulting from this process do not represent the average cost of production in a statistical sense, and the production practices listed are not necessarily recommended production practices. The intent of these cost budgets is to establish a benchmark within a comprehensive range of potential costs that could be expected to produce the crop. The budget also contains a Your Cost column that enables you to enter your individual expenses for comparative purposes.

The production budget for 2008 indicates that the pre-harvest variable costs for bell peppers in southwest Florida totaled an estimated \$7,282 per acre, an increase of 20 percent over pre-harvest variable costs estimated in 2006 . The fixed costs for a representative grower totaled $\$ 4,403$ per acre in 2008, a 20 percent increase over the fixed costs in 2006. With an assumed yield of 1,000 bushels per acre, harvest and marketing costs totaled $\$ 4,450$ per acre, bringing the total cost of production to an estimated $\$ 16,134$ per acre, or $\$ 16.13$ per bushel, an increase of 13 percent over the 2006 costs. The cost item that has increased most significantly since the 2005-06 budget is fertilizer, which increased 315 percent. Overall, labor costs (general farm labor and tractor driver wages), miscellaneous costs (including hand weeding, driving stakes, tying plants, plastic mulch disposal preparation), and transplants increased 10 percent, 2 percent, and 11 percent, respectively, over this period.

\section{Additional Resources}

We have developed interactive workbooks containing data used to create the UF/IFAS estimated budget in Table 2 . These workbooks can be used to produce cost estimates broken down by specific groups (e.g., herbicide). Included in these workbooks are pesticide worksheets listing all of the currently labeled pesticides so that users can estimate their own pesticide costs, and machinery worksheets listing the machinery cost coefficients so that users can estimate their own fixed and variable costs. The International Agricultural Trade and Policy Center internet site (http://www.iatpc.ifas.ufl.edu) contains a link to download these interactive Excel workbooks. These workbooks enable users to compare their production expenses to the UF/IFAS estimates presented. These workbooks may be saved to your computer and printed in their entirety or printed as individual worksheets.

The following information is provided as a convenience to your research and decision making efforts.

- Botany: Family-Solanaceae, Pepper-Capsicum annuum

- Related crops in the Solanaceae Family: Tomato, Potato, Eggplant

- Common Bell Pepper Varieties for Commercial Production:

- Common Varieties: Aladdin, Aristotle, Brigadier, Crusader, Double-Up, Enterprise-X3R, Excursion II, Heritage, Lafayette, Legionnaire, Olympus, Orion, Paladin, Patriot, Polaris, Revolution, Sentry, Snapper, Telestar, Wizard-X3R.

- Specialty Varieties: Cubanelle, Aruba, Biscayne, Key Largo, Ancho Villa, Cherry Bomb, Grande, Hercules, Inferno, Large Red Thick, Mesilla, Mitla, Ventura.

For further information on pepper production in Florida please refer to EDIS publication HS732 (http://edis.ifas.ufl.edu/CV130) or contact your local Extension specialists.

\section{References}

Olson, S.M., Simone, W.M. Stall, K.L. Pernezny, S.E. Webb, T.G. Taylor and S.A. Smith. 2007. Chapter 34, Pepper Production in Florida. In Vegetable Production Handbook for Florida 2006-2007. Electronic Data Information Source (EDIS) CV130. Horticultural Sciences Department, University of Florida, Gainesville, FL. http://edis.ifas.ufl.edu/CV130

USDA/NASS. 2009. Crop Statistics. United States Department of Agriculture, National Agricultural Statistics Service, Washington, D.C. http://quickstats.nass.usda.gov/ 
Table 1. Florida bell pepper acreage, production, and value, crop years, 2002-03 through 2006-07.

\begin{tabular}{|lcccccc|}
\hline \hline Season & Planted & Harvested & Yield & Production & Unit Value & Total Value \\
\cline { 2 - 3 } & (acres) & (acres) & (28-lb bushels) & $(1,000$ bushels $)$ & (dollars) & $(1,000$ dollars $)$ \\
\hline $2002-03$ & 17,800 & 17,700 & 1,000 & 17,700 & 10.05 & 177,920 \\
$2003-04$ & 18,500 & 18,300 & 1,107 & 20,261 & 10.78 & 218,411 \\
$2004-05$ & 19,400 & 19,000 & 861 & 16,357 & 13.05 & 213,428 \\
$2005-06$ & 19,800 & 16,500 & 876 & 14,450 & 12.96 & 187,330 \\
$2006-07$ & 18,000 & 17,500 & 886 & 15,500 & 11.82 & 183,148 \\
\hline Source: USDA/NASS, http://quickstats.nass.usda.gov/ & & & \\
\hline \hline
\end{tabular}

Table 2. Estimated costs of producing one acre of bell peppers in southwest Florida, 2007-08.

\begin{tabular}{|c|c|c|c|c|c|}
\hline \multirow{2}{*}{ Based on Yield of 1,100 Units Per Acre } & Unit & Quantity & Price & Value & Your Cost \\
\hline & & & (dollars) & (dollars) & \\
\hline \multicolumn{6}{|l|}{ Pre-Harvest Variable Costs } \\
\hline Transplants & & & & $1,000.00$ & \\
\hline Fertilizer, mixed and lime & & & & $1,438.50$ & \\
\hline Fumigant & & & & 600.00 & \\
\hline Herbicide & & & & 31.19 & \\
\hline Insecticide & & & & 630.55 & \\
\hline Fungicide & & & & 307.71 & \\
\hline Tractor + machinery & & & & $1,190.42$ & \\
\hline Truck (pickup) & & & & 39.00 & \\
\hline Labor & & & & 452.36 & \\
\hline Plastic mulch & & & & 330.00 & \\
\hline Scouting & & & & 35.00 & \\
\hline Level land & & & & 100.00 & \\
\hline Drive stakes & & & & 83.49 & \\
\hline String, stakes, and plastic disposal & & & & 399.30 & \\
\hline Stakes & & & & 120.00 & \\
\hline Tie plants & & & & 36.30 & \\
\hline Interest on operating capital (10\%) & & & & 462.76 & \\
\hline Total Pre-Harvest Variable Costs & & & & $7,281.58$ & \\
\hline
\end{tabular}


Table 2. Estimated costs of producing one acre of bell peppers in southwest Florida, 2007-08.

\begin{tabular}{|c|c|c|c|c|c|}
\hline \multirow[t]{2}{*}{ Based on Yield of 1,100 Units Per Acre } & Unit & Quantity & Price & Value & Your Cost \\
\hline & & & (dollars) & (dollars) & \\
\hline \multicolumn{6}{|l|}{ Pre-Harvest Fixed Costs } \\
\hline Tractor + machinery & & & & 253.29 & \\
\hline Land rent & & & & 500.00 & \\
\hline Overhead and management & & & & $3,649.23$ & \\
\hline Total Pre-Harvest Fixed Costs & & & & $4,402.52$ & \\
\hline Total Pre-Harvest Costs & & & & $11,684.10$ & \\
\hline \multicolumn{6}{|l|}{ Harvest and Marketing Costs } \\
\hline Pick/pack/haul & bushel & 1,000 & 3.00 & $3,000.00$ & \\
\hline Sell & bushel & 1,000 & 0.50 & 500.00 & \\
\hline Containers & each & 1,000 & 0.95 & 950.00 & \\
\hline Total Harvest and Marketing Costs & & & & $4,450.00$ & \\
\hline Total Costs & & & & $16,134.10$ & \\
\hline
\end{tabular}

